\title{
PERTANGGUNGJAWABAN PIDANA PEJABAT PEMBUAT KOMITMEN SEBAGAI UPAYA PENCEGAHAN KORUPSI PENGADAAN BARANG/JASA PEMERINTAH
}

\author{
Vita Mahardhika
}

\author{
Fakultas Ilmu Sosial dan Hukum, Universitas Negeri Surabaya \\ Kampus Ketintang, Jalan Ketintang Surabaya, 60231 \\ vitamahardhika@unesa.ac.id
}

\begin{abstract}
One form of corruption is irregularities in the process of procuring government goods/services that harm the state finances or the country's economy. These deviations generally occur due to officials who are negligent or not careful in understanding and implementing the provisions of laws and regulations. The Commitment Making Officer (PPK) is a very crucial position, this is because the PPK plays a role in every stage of the procurement of government goods/services. Therefore, the competence of KDP must be considered not only in the field of goods/services procurement, managerial competence, and good morals and ethics are also very important. The parameter of criminal responsibility by PPK is an element of acts against the law with abuse of authority in accordance with article 2 paragraph (1) and Article 3 of Law Number 31 of 2009 as amended by Law Number 20 of 2001 concerning the Eradication of Corruption Crime. is normative law research with statutory, conceptual, and case approaches related to the topic of discussion.
\end{abstract}

Keywords: procurement of government goods/services; criminal liability; the committing officer (PPK).

\begin{abstract}
Intisari, Salah satu bentuk tindak pidana korupsi adalah penyimpangan dalam proses pengadaan barang/jasa pemerintah yang merugikan keuangan negara atau perekonomian negara. Penyimpangan tersebut pada umumnya terjadi karena pejabat yang lalai atau tidak cermat dalam memahami dan melaksanakan ketentuan dalam peraturan perundang-undangan. Pejabat Pembuat Komitmen (PPK) merupakan jabatan yang sangat krusial, hal ini dikarenakan PPK berperan dalam setiap tahapan pengadaan barang/jasa pemerintah. Oleh karena itu kompetensi PPK harus sangat diperhatikan tidak hanya di bidang pengadaan barang/jasa, kompetensi manajerial, serta moral dan etika yang baik juga sangat penting. Paramater pertanggungjawaban pidana oleh PPK merupakan unsur perbuatan melawan hukum dengan penyalahgunaan wewenang sesuai dengan pasal 2 ayat (1) dan pasal 3 Undang-Undang Nomor 31 Tahun 2009 sebagaimana diubah dengan Undang-Undang Nomor 20 Tahun 2001 tentang Pemberantasan Tindak Pidana Korupsi.. Penelitian ini adalah penelitian hukum normatif (normatif law research) dengan pendekatan perundang-undangan, konseptual, dan kasus yang barkaitan dengan topik bahasan.
\end{abstract}

Kata kunci: pengadaan barang/jasa pemerintah; pertanggungjawaban pidana; Pejabat Pembuat Komitmen (PPK).

\section{Pendahuluan}

Pemberantasan korupsi dalam upaya pembangunan nasional semakin meningkat, peran masyarakat dalam upaya mewujudkan wilayah bebas korupsi sangat membantu dalam upaya pemerintah memberantas korupsi. Peran serta lembaga pemerintah juga 
tidak kalah pentingnya yaitu dengan menyusun roadmap reformasi birokrasi yang salah satu programnya adalah menciptakan Zona Integritas menuju Wilayah Bebas Korupsi (WBK) dan WBBM (Wilayah Birokrasi Bersih dan Melayani). Hal ini sangat terkait sehubungan dengan pernyataan Ketua Lembaga Kebijakan Pengadaan Barang/Jasa, Roni Dwi Susanto bahwa kasus korupsi pengadaan barang/jasa pemerintah menduduki posisi ke-2 dalam kasus yang ditangani KPK. ${ }^{1}$ Oleh karena itu upaya pemberantasan korupsi pada lembaga pemerintahan terutama dalam sektor pengadaan barang/jasa menjadi perhatian serius.

Pendistibrusian anggaran belanja negara salah satunya melalui pengadaan barang/jasa pemerintah yang merupakan komponen fundamental dalam mewujudkan pemerintahan yang baik. Pengadaan barang/jasa pemerintah memiliki tujuan antara lain memperoleh barang/jasa dengan harga dapat dipertanggungjawabkan dengan jumlah dan mutu sesuai serta tepat waktu dalam pelaksanaannya. Mengingat pembiayaan pengadaan barang/jasa pemerintah berasal dari pajak setiap warga negara, maka pengaturan dalam proses pengadaan barang/jasa harus sesuai dengan peraturan perundangan-undangan sehingga memiliki akuntabilitas dan tanpa mengurangi efektifitas dalam pelaksanaannya.

Sebenarnya sejak tahun 1960, isu dan permasalahan pengadaan barang/jasa telah mendapat perhatian masyarakat internasional, dan berbagai upaya telah dilakukan untuk mencari solusinya. ${ }^{2}$ Dalam Ihtisar Hasil Pemeriksaan Semester II Tahun 2019 (IHPS II 2019), Badan Pemeriksaan Keuangan Republik Indonesia (BPK RI), mengungkapkan 4.094 temuan yang memuat 5.480 permasalahan, meliputi 971 (18\%) permasalahan kelemahan sistem pengendalian intern (SPI) dan 1.725 (31\%) permasalahan ketidakpatuhan terhadap ketentuan peraturan perundang-undangan sebesar Rp6,25 triliun, serta 2.784 (51\%) permasalahan ketidakhematan, ketidakefisienan, dan ketidakefektifan sebesar Rp1,35 triliun. Dapat dilihat dalam IHPS II 2019 tersebut bahwa ketidakpatuhan pemerintah daerah terhadap ketentuan perundang-undangan yang mengakibatkan kerugian negara sebesar Rp. 6,25 triliun. Tingginya kasus korupsi di Indonesia tentu menjadi preseden buruk bagi perekonomian Indonesia.

Pemenuhan layanan publik yang prima dan berkualitas dengan pembangunan manusia maupun pembangunan fisik merupakan tujuan negara dalam melakukan percepatan pembangunan nasional. Dalam pembangunan fisik tentunya negara harus mengimbangi dengan penataan regulasi yang baik terkait dengan pengadaan barang/jasa. Seiring dengan tujuan pengadaan yang dapat memberikan pemenuhan nilai manfaat yang sebesar-besarnya (value for money) maka ditetapkan dalam salah satu tujuan adalah menghasilkan barang/jasa yang tepat dari setiap uang yang dibelanjakan yang diukur dari aspek kualitas, jumlah, waktu, biaya, lokasi dan penyedia.

1 https://Nasional.Kompas.Com/Read/2019/11/06/11253441/Lkpp-Korupsi Pengadaan -BarangDan-Jasa-Peringkat-2-Di-Kpk'. Diakses pada tanggal 9 September 2020.

${ }^{2}$ Stuart G.G. Christoper M, 'WTO Government Procurement Rules and the Local Dynamics of Procurement Policies: A Malaysian Case Study', The European Journal of International Law, Vol. 17 no (2006). 
BPK RI menjelaskan bahwa permasalahan yang mengakibatkan kerugian keuangan negara banyak ditemukan dalam pengelolaan belanja modal dan belanja barang/jasa. Hal ini terjadi karena pejabat yang bertanggungjawab lalai dan tidak cermat dalam mentaati dan mematuhi ketentuan yang berlaku, belum optimal melaksanakan tugas dan fungsinya, lemah dalam pengawasan, serta sengaja tidak mempertanggungjawabkan pengelolaan anggaran. Korupsi senantiasa melibatkan lebih dari satu orang. Hal ini tidak sama dengan kasus pencurian atau penipuan. Seorang operator korup sesungguhnya tidak ada dan kasus itu biasanya termasuk dalam pengertian penggelapan $($ fraud $){ }^{3}$

Dalam semua tahapan pengadaan barang/jasa pemerintah terdapat konsekuensi pertanggungjawaban hukum meliputi hukum administrasi, hukum perdata, dan hukum pidana. Ketidakpahaman terhadap peraturan perundang-undangan terkait pengadaan barang/jasa pemerintah, mengakibatkan adanya perbuatan penyimpangan dalam melaksanakan proses pengadaan. Hal inilah yang akan menjadi pintu timbulnya kerugian keuangan negara. Penyalahgunaan keuangan negara merupakan perbuatan melawan hukum yang menjadi salah satu unsur dalam tindak pidana korupsi. Korupsi yang terjadi di Indonesia terjadi secara meluas sehingga tidak cukup jika hanya dikatakan merugikan keuangan Negara tetapi juga melanggar hak-hak social dan ekonomi masyarakat secara luas.

Pelaksanaan pengadaan barang dan jasa selama ini banyak menimbulkan persoalan dimulai sejak perencanaan hingga serah terima pekerjaan. Pada umumnya, pelaku dijerat dengan Pasal 3 jo Pasal 18 ayat (1) huruf b Undang-Undang Nomor 31 Tahun 1999 sebagaimana diubah dengan Undang-Undang Nomor 20 Tahun 2001 tentang perubahan atas Undang-Undang Nomor 31 tahun 1999 tentang Pemberantasan Tindak Pidana Korupsi. ${ }^{4}$

Dalam beberapa kasus tindak pidana korupsi, pejabat yang bertanggungjawab adalah Pejabat Pembuat Komitmen (PPK) yang dalam hal ini pejabat yang melaksanakan pendelegasian kewenangan dari Pengguna Anggaran/Kuasa Pengguna Anggaran. Karena PPK selaku pelaku pengadaan barang/jasa pemerintah yang dapat mengakibatkan terjadinya kerugian negara atau perekonomian negara. Pemenuhan tanggungjawab oleh PPK dibedakan menjadi tanggung jawab jabatan yang bertumpu pada kesalahan jabatan yaitu kesalahan dalam menggunakan wewenang dan tanggung jawab pidana yang merupakan tanggungjawab pribadi yang bertumpu pada kesalahan pribadi dalam pelaksanaan pengadaan barang/jasa. ${ }^{5}$

Pembahasan penelitian ini memfokuskan pada rumusan masalah bagaimana pengaturan tentang kompetensi yang harus dimiliki oleh PPK dan bagaimana pertanggungjawaban pidana PPK terkait dengan penyimpangan dalam proses pengadaan barang/jasa pemerintah. Kompetensi adalah hal mutlak yang harus dimiliki oleh seorang yang mengemban suatu jabatan dan tanggungjawab. Dalam setiap jabatan pasti akan

\footnotetext{
${ }^{3}$ Evi Hartanti, Tindak Pidana Korupsi (Jakarta: Sinar Grafika, 2009).

${ }^{4}$ Iriyanto Tiranda, 'Konsep Ideal Penanganan Perkara Tindak Pidana Korupsi Pungutan Liar Berdasarkan Asas Peradilan', Jambura Law Review, 1 (2019), 123.

${ }^{5}$ Amiruddin, Korupsi Dalam Pengadaan Barang Dan Jasa (Yogyakarta: Genta Publishing, 2010).
} 
mensyaratkan kompetensi yang menggambarkan kualifikasi dan keahlian tertentu yang harus dimiliki oleh seorang yang memegang jabatan. Begitupun dengan jabatan PPK. Sedangkan seiring dengan jabatan yang diemban maka timbullah suatu tanggungjawab. Karena tugas PPK adalah selalu bersinggungan dengan penggunaan uang negara, maka segala tindakan yang dilakukan harus sesuai dengan koridor peraturan perundangundangan. Tidak jarang PPK berurusan dengan penegak hukum dalam kaitannya dengan tugasnya sebagai seorang PPK. Oleh karena itu pertanggungjawaban pidana oleh PPK diharapkan menjadi upaya pencegahan dalam melakukan tindak pidana korupsi.

Metode penelitian yang digunakan adalah penelitian yuridis normatif, merupakan penelitian yang mengkaji dan menganalisis peraturan perundang-undangan yang berkaitan dengan permasalahan yang sedang diangkat. ${ }^{6}$ Pendekatan yang digunakan dalam penelitian ini adalah pendekatan undang-undang (statute approach) dengan menelaah beberapa undang-undang dan regulasi yang bersangkut paut dengan isu hukum yang ditangani, pendekatan kasus (case approach) dengan telaah terhadap kasus yang berkaitandengan isu yang dihadapi, pendekatan historis (historical approach) dengan menelaah latar belakang apa yang dipelajari dan perkembangan pengaturan mengenai isu yang dihadapi, pendekatan konseptual (konseptual approach) beranjak dari pandanganpandangan dan doktrin-doktrin yang berkembang di dalam ilmu hukum. ${ }^{7}$

\section{Hasil Penelitian dan Pembahasan}

\section{A. Kompetensi Pejabat Pembuat Komitmen}

Berdasarkan Kamus Umum Bahasa Indonesia, kompetensi adalah kewenangan untuk menentukan sesuatu. Menurut Sedarmayanti, kompetensi adalah karakteristik mendasar yang dimiliki seseorang yang berpengaruh langsung terhadap atau dapat memprediksikan prestasi kerja yang sangat baik. $^{8}$ Kompetensi merupakan suatu kemampuan melaksanakan suatu pekerjaan yang dilandasi atas ketrampilan dan pengetahuan, serta didukung oleh sikap kerja yang professional.

Dalam Peraturan Presiden Nomor 16 Tahun 2018 sebagaimana diubah oleh Perpres Nomor 12 Tahun 2021 tentang Pengadaan Barang/Jasa Pemerintah (selanjutnya disebut Perpres No. 12 Tahun 2021), pasal 1 angka 1 menyebutkan, pengadaan barang/jasa adalah kegiatan pengadaan barang/jasa oleh kementerian/lembaga/perangkat daerah yang dibiayai oleh ABPN/APBD yang prosesnya sejak identifikasi kebutuhan sampai dengan serah terima hasil pekerjaan. Sedangkan dalam pasal 8 Perpres No. 12 Tahun 2021 disebutkan pelaku pengadaan barang/jasa terdiri atas:

a. Pengguna Anggaran (PA);

b. Kuasa Pengguna Anggaran (KPA);

c. Pejabat Pembuat Komitmen (PPK);

\footnotetext{
${ }^{6}$ Zainal Asikin, et al., Pengantar Metode Penelitian Hukum, (Jakarta: Rajawali Pers, 2016).

${ }^{7}$ Peter Mahmud Marzuki, Penelitian Hukum, (Jakarta:Kencana, 2009).

8 Sedarmayanti, Manajemen Sumber Daya Manusia: Reformasi Birokrasi dan Manajemen Pegawai Negeri Sipil, (Bandung:Refika Aditama, 2007).
} 
d. Pejabat Pengadaan;

e. Pokja Pemilihan;

f. Agen Pengadaan;

g. Penyelenggara Swakelola;

h. Penyedia. ${ }^{9}$

Penelitian ini membahas tentang tugas dan fungsi serta tanggung jawab Pejabat Pembuat Komitmen (PPK) yang erat kaitannya dengan kompetensi dalam proses pengadaan barang/jasa pemerintah sebagai upaya pencegahan korupsi. Dalam pasal 11 ayat (1) Perpres No. 12 Tahun 2021 disebutkan bahwa tugas PPK adalah

a. Menyusun perencanaan pengadaan;

b. Melaksanakan konsolidasi Pengadaan Barang/Jasa;

c. Menetapkan spesifikasi teknis/Kerangka Acuan Kerja;

d. Menetapkan rancangan kontrak;

e. Menetapkan HPS;

f. Menetapkan besaran uang muka yang akan dibayarkan kepada Penyedia;

g. Mengusulkan perubahan jadwal kegiatan;

h. Melaksanakan e-purchasing untuk nilai paling sedikit di atas Rp. 200.000.000,00 (dua ratus juta rupiah);

i. Mengendalikan kontrak;

j. Menyimpan dan menjaga keutuhan seluruh dokumen pelaksanaan kegiatan

k. Melaporkan pelaksanaan dan penyelesaian kegiatan kepada PA/KPA;

1. Menyerahkan hasil pekerjaan pelaksanaan kegiatan kepada PA/KPA dengan berita acara penyerahan;

m. Menilai kinerja Penyedia

n. Menetapkan tim pendukung;

o. Menetapkan tim ahli atau tenaga ahli; dan

p. Menetapkan Surat Penunjukan Penyedia Barang/Jasa. ${ }^{10}$

Selain melaksanakan tugas sebagaimana dimaksud pada ayat (1), PPK melaksanakan tugas pelimpahan dari PA/KPA meliputi:

a. Melakukan tindakan yang mengakibatkan pengeluaran anggaran belanja; dan

${ }^{9}$ Lihat pasal 8 Peraturan Presiden Nomor 12 Tahun 2021 tentang Perubahan atas Peraturan Presiden Nomor 16 Tahun 2018 tentang Pengadaan Barang/Jasa Pemerintah.

${ }^{10}$ Lihat pasal 11 ayat 1 Peraturan Presiden Nomor 12 Tahun 2021 tentang Perubahan Peraturan Presiden Nomor 16 Tahun 2018 tentang Pengadaan Barang/Jasa Pemerintah. 
b. Mengadakan dan menetapkan perjanjian dengan pihak lain dalam batas anggaran yang telah ditetapkan.

Syarat untuk dapat diangkat menjadi PPK sesuai dengan Peraturan Lembaga LKPP Nomor 19 Tahun 2019 adalah

1. Memiliki integritas dan disiplin;

2. Menandatangani pakta integritas;

3. Memiliki sertifikat kompetensi dibidang Pengadaan Barang/Jasa, jika tidak dapat terpenuhi, sertifikat keahlian tingkat dasar dapat digunakan sampai dengan 31 Desember 2023; dan

4. Berpendidikan paling rendah Strata satu (S1) atau setara. Jika tidak terpenuhi, persyaratan Sarjana Strata Satu (S1) dapat diganti dengan memiliki golongan ruang paling rending III/a atau disetarakan dengan golongan III/a.

Persyaratan dapat ditambahkan dengan:

1. Memiliki latar belakang keilmuan dan pengalaman yang sesuai dengan pekerjaan; atau

2. Memiliki kompetensi teknis pada bidang masing-masing sesuai dengan ketentuan peraturan perundangan-undangan.

Lebih lanjut dijelaskan bahwa sertifikat keahlian adalah seluruh kegiatan yang dilakukan oleh LKPP untuk menentukan bahwa seseorang telah memenuhi persyaratan kompetensi yang ditetapkan mencakup permohonan, evaluasi, keputusan sertifikasi, surveilen, dan sertifikasi ulang. Sertifikasi keahlian pengadaan barang/jasa adalah pengakuan dari pemerintah atas kompetensi dan kemampuan profesi di bidang barang/jasa. Sedangkan tujuan diselenggarakannya sertifikasi keahlian antara lain:

a. Memastikan bahwa pengelolaan pengadaan barang/jasa dilakukan oleh sumber daya manusia yang professional.

b. Membantu sistem pengembangan karier dan profesi sumber daya manusia di bidang pengadaan barang/jasa.

PPK sebagai pelaksana pengadaan barang/jasa bekerja sesuai dengan ketentuan dalam Perpres No. 12 Tahun 2021 dengan menerapkan prinsip efisien, efektif, transparan, terbuka, bersaing, adil, dan akuntabel. Salah satu poin penting dalam etika pengadaan barang/jasa adalah semua pihak menghindari dan mencegah pemborosan dan kebocoran keuangan negara serta menghindari dan mencegah penyalahgunaan wewenang dan/atau kolusi. Karena disinilah potensi korupsi ditemukan. Untuk itu peran PPK sangat penting dalam upaya pencegahan korupsi dalam pengadaan barang/jasa. PPK bertanggung jawab terhadap hampir seluruh tahapan pengadaan barang/jasa, maka dapat diartikan PPK bertanggung jawab seluruh aspek yaitu aspek administrasi, teknis, dan finansial terhadap proses pengadaan barang/jasa yang dilaksanakannya. ${ }^{11}$

\footnotetext{
${ }^{11}$ Lihat pasal 11 ayat 1 Peraturan Presiden Nomor 12 Tahun 2021 tentang Perubahan Peraturan Presiden Nomor 16 Tahun 2018 tentang Pengadaan Barang/Jasa Pemerintah.
} 
Skala manajemen pekerjaan pengadaan barang/jasa pemerintah yang dapat dikelompokkan mulai dari yang sederhana sampai dengan yang paling komplek, dapat menjadi standar untuk mengelompokkan kompetensi PPK berdasarkan dengan pekerjaan yang dilakukannya. Dalam Surat Edaran LKPP Nomor 8 Tahun 2020 tentang Tipologi Pejabat Pembuat Komitmen dan Standar Kompetensi Pengadaan Barang/Jasa Pemerintah Untuk Pejabat Pembuat Komitmen, mengelompokkan PPK menjadi tiga tipologi serta standar kompetensi Pengadaan Barang/jasa Pemerintah untuk PPK.

Tipologi PPK dibagi menjadi Tipe A, Tipe B, dan Tipe C. Gradasi dalam tipologi ini terletak pada perbedaan skala pekerjaan antara PPK satu dengan yang lain. PPK Tipe A adalah PPK yang menangani pekerjaan dengan kategori manajemen kontrak yang kompleks, yaitu yang memiliki resiko tinggi, memerlukan teknologi tinggi, menggunakan peralatan yang didesain khusus, menggunakan penyedia jasa asing, dan/atau sulit mendefinisikan secara teknis bagaimana cara memenuhi kebutuhan dan tujuan pengadaan barang/jasa, misalnya pengadaan satelit, pembangunan bendungan, pekerjaan penambangan sumber daya alam mineral bawah laut dan lain lain. Sedangkan PPK Tipe $\mathrm{B}$ adalah PPK yang menangani pekerjaan dengan kategori manajemen kontrak yang umum atau lazim ada dalam suatu organisasi, namun tidak termasuk dalam kategori pekerjaan kompleks dan/atau sederhana, misalnya belanja mobil, belanja eskavator, konsultan perencanaan jembatan, dan lain lain. Untuk PPK Tipe C adalah PPK yang menangani pekerjaan dengan kategori manajeman kontrak sederhana, yakni yang bersifat operasional, rutin, standar, dan/atau berulang/repetisi, misalnya pengadaan alat tulis kantor, konsumsi rapat, jasa kebersihan dan lain lain. ${ }^{12}$

Tetapi menarik apabila kita simak penjelasan Khalid Mustofa ${ }^{13}$, dalam web blognya https://www.khalidmustafa.info/ menjelaskan bahwa yang bertanggungjawab dalam menerima hasil pekerjaan adalah PPK, tetapi apabila seorang PPK menangani berpuluh-puluh pengadaan, apakah sanggup seorang PPK memeriksa semua hasil pekerjaan. Disinilah filosofi dasar dalam Peraturan Lembaga LKPP No 15 Tahun 2018 salah satu syarat untuk menjadi PPK adalah memiliki kemampuan manajerial level tiga, yang artinya PPK adalah seorang manajer bukan hanya pelaksana sehingga apabila ada tugas dan kewenangan yang berkaitan dengan proses pengadaan bukan berarti PPK yang turun lapangan langsung. PPK diberi kewenangan untuk menetapkan tim pendukung dan tim ahli dalam membantu tugas-tugasnya sebagai PPK. ${ }^{14}$ Kewenangan membentuk tim pendukung dan tim ahli masih diatur dalam pasal 11 Perpres No 12 Tahun 2021 yang dimana dalam pasal tersebut ada sedikit perubahan tentang tugas PPK yaitu ada tambahan tugas bahwa seorang PPK melaksanakan konsolidasi pengadaan barang/jasa. Tanggung jawab untuk penyelesaian menjadi tanggung renteng antara PPK dan tim pendukung atau tim ahli, maka apabila PPK tidak mempunyai kemampuan, kompetensi, dan waktu maka

\footnotetext{
${ }^{12}$ Lihat Surat Edaran LKPP Nomor 8 Tahun 2020 tentang Tipologi Pejabat Pembuat Komitmen dan Standar Kompetensi Pengadaan Barang/Jasa Pemerintah Untuk Pejabat Pembuat Komitmen.

${ }^{13}$ PPK tidak boleh "one man show" dalam https://www.khalidmustafa.info/, diakses pada tanggal 9 September 2020.

${ }^{14}$ Lihat Pasal 11 Peraturan Presiden Nomor 16 Tahun 2018 tentang Pengadaan Barang/Jasa Pemerintah.
} 
bentuklah tim pendukung/tim ahli yang kuat dan tangguh untuk membantu melakukan tugas sebagai PPK. Inilah satu makna bahwa PPK adalah manajer bukan "one man show". Meskipun sekarang Peraturan Lembaga LKPP No. 15 Tahun 2018 dirubah dengan Peraturan Lembaga LKPP No. 19 Tahun 2018 yang menghapus syarat bahwa PPK harus memiliki kemampuan manajerial level tiga, akan tetapi menurut penulis jika melihat kembali Perpres No. 16 Tahun 2018 yang mana PPK mempunyai kewenangan membentuk tim pendukung atau tim ahli, maka kemampuan manajerial masih sangat diperlukan untuk jabatan PPK.

PPK tidak bekerja hanya pada akhir tahapan pengadaan, tetapi PPK sudah mulai berperan sejak awal tahapan pengadaan barang/jasa. Sehingga ada anggapan bahwa PPK merupakan jabatan yang "strategis" atau "memakmurkan" orang yang menjabatnya. Pada era lama banyak pejabat struktural yang menginginkan untuk menjadi PPK. Tetapi di era sekarang, jabatan PPK menjadi momok bagi birokrat, alasannya karena jabatan PPK sangat rentan dengan masalah hukum. ${ }^{15}$

\section{B. Pertanggungjawaban Pidana Pejabat Pembuat Komitmen}

Setiap perbuatan mempunyai konsekuensi yang harus dipertanggungjawabkan menurut ketentuan hukum yang berlaku. Berbicara mengenai pertanggungjawaban pidana, dalam doktrin hukum pidana terdapat dua pandangan yang lazim digunakan untuk dapatnya seseorang dimintai pertanggungjawaban pidana yaitu aliran monistis dan monisme yang oleh Simon dirumuskan sebagai berikut:

Menurut aliran monistis suatu perbuatan yang oleh hukum diancam dengan hukuman, bertentangan dengan hukum, dilakukan oleh seorang yang bersalah dan orang itu dianggap bertanggungjawab atas perbuatannya). Menurut aliran monisme, unsur-unsur strafbaar feit itu meliputi baik unsur perbuatan yang lazim dinamakan unsur objektif, maupun unsur pembuat, yang lazim dinamakan unsur subjektif. Karena itu, dicampurnya unsur pembuatnya, maka dapatlah disimpulkan bahwa strafbaar feit adalah sama dengan syarat-syarat penjatuhan pidana, sehingga seolah-olah dianggap bahwa kalau terjadi straafbaar feit, maka pasti pelakunya dapat dipidana. ${ }^{16}$

Menurut Roeslan Saleh bahwa "seseorang melakukan perbuatan pidana akan dipidana apabila pelaku mempunyai kesalahan". ${ }^{17}$ Sesuai dengan asas hukum pidana "tidak pidana tanpa kesalahan", unsur kesalahan merupakan yang utama dalam menuntut pertanggungjawaban pidana atas perbuatan seseorang. Unsur kesalahan adalah keadaan batin pelaku yang menghubungkan antara perbuatan dan akibat serta sifat melawan hukum yang memuat unsur kesengajaan (dolus) atau unsur kealpaan (culpa).

\footnotetext{
${ }^{15}$ Mita Kristiani, 'Perlindungan Hukum Terhadap Pejabat Pembuat Komitmen (PPK) dalam Pengadaan Barang/Jasa Pemerintah pada Sistem Pengadaan secara Elektronik', Jurnal Legal Spirit, 4 (2020), DOI: https://doi.org/10.31328/ls.v4i1.1552.

${ }^{16}$ Muladi Dwidja Priyatno, Pertanggungjawaban Pidana Korporasi (Jakarta: Prenada Media Group, 2015).

${ }^{17}$ Roeslan Saleh, Perbuatan Pidana dan Pertanggungjawaban Pidana, (Jakarta:Aksara Baru, 1981) hlm 81 .
} 
Pertanggungjawaban pidana oleh PPK dalam hal terjadi kerugian keuangan negara, dapat dilihat dari tindakan/perbuatan atau pengambilan keputusan yang diambil oleh PPK dalam setiap tahapan pada proses pengadaan barang/jasa. Suatu perbuatan atau tindakan yang dirumuskan sebagai perbuatan/tindak pidana harus memenuhi beberapa persyaratan. Menurut Moeljatno, perbuatan pidana adalah perbuatan yang dilarang oleh suatu aturan hukum larangan mana disertai ancaman (sanksi) yang berupa pidana tertentu, bagi barang siapa yang melanggar larangan tersebut. Dapat juga dikatakan bahwa perbuatan pidana adalah perbuatan yang oleh suatu aturan hukum dilarang dan diancam pidana, asal saja dalam pada itu diingat bahwa larangan ditujukan kepada perbuatan (yaitu suatu keadaan atau kejadian yang ditimbulkan oleh kelakuan orang) sedangkan ancaman pidananya ditujukan kepada yang menimbulkan kejadian itu. ${ }^{18}$

Pemenuhan tanggungjawab PPK melahirkan batasan tanggungjawab hukum yang berbeda, yaitu tanggungjawab bidang hukum pidana, hukum perdata, dan hukum administrasi. Dalam hal tanggungjawab pidana, hal ini timbul karena ada hubungan hukum antara PPK dengan pihak ketiga atau penyedia barang/jasa yang dimulai dari tahap persiapan sampai dengan serah terima hasil pekerjaan kemudian dilakukan prestasi oleh PPK. Karena konsep tanggungjawab pidana adalah adanya perbuatan pidana atau "actus reus" dan kesalahan atau "mens rea" yang diwujudkan dalam bentuk kesengajaan dan kealpaan. Sehingga yang menjadi parameter adanya tanggungjawab PPK secara pidana adalah adanya unsur perbuatan melawan hukum dengan penyalahgunaan wewenang yang didasari atas kesalahan baik yang bersifat sengaja maupun lalai sehingga mengakibatkan kerugian keuangan negara dan perekonomian negara.

Sedangkan tanggungjawab secara perdata, muncul dari adanya hubungan hukum antara PPK dengan pihak ketiga atau penyedia barang/jasa sejak penandatanganan kontrak sampai dengan berakhirnya kontrak. Apabila terjadi perselisihan antara PPK dengan penyedia barang/jasa misalnya penyedia melakukan wanprestasi maka diselesaikan dengan mekanisme hukum perdata.

Dalam hal tanggungjawab secara hukum administrasi, dimana ada hubungan hukum antara PPK dengan pihak ketiga atau penyedia barang/jasa terkait keputusan pejabat yang berwenang misalnya dalam penyusunan HPS, spesifikasi teknis, penerbitan Surat Penunjukan Penyedia Barang/Jasa Pemerintah (SPPBJ). Bilamana PPK terbukti melanggar ketentuan yang berlaku maka sanksi administratif dikenakan kepada PPK berupa hukuman disiplin ringan, sedang, atau berat oleh Pejabat Pembina Kepegawaian atau pejabat yang berwenang sesuai undang-undang. Penyimpangan karena adanya kesalahan administrasi yang dilakukan oleh PPK berimplikasi kepada pertanggungjawaban pidana jika terbukti memenuhi unsur dalam tindak pidana korupsi.

Wakil Ketua Komisi Pemberantasan Korupsi (KPK) Nawawi Pomolango menyebutkan, 70 persen kasus tindak pidana korupsi yang ditangani KPK berkaitan dengan sektor pengadaan barang dan jasa. "Kasus yang ditangani Komisi Pemberantasan misalnya sampai hari ini masih tercatat 70 persen itu dari soal pengadaan barang dan jasa," kata Nawawi dalam acara Aksi Nasional Pencegahan Korupsi yang disiarkan akun

${ }^{18}$ Moeljatno, Asas-Asas Hukum Pidana (Jakarta: Rineka Cipta, 2008). 
Youtube KPK, Rabu (26/8/2020). Nawawi menuturkan, persentase itu dapat meningkat karena banyak kasus suap yang ditangani KPK yang juga berkaitan dengan pengadaan barang dan jasa. ${ }^{19}$

Korupsi menurut Kamus Umum Bahasa Indonesia adalah perbuatan yang buruk seperti penggelapan uang, penerimaan uang sogok dan sebagainya. Dalam prakteknya korupsi lebih dikenal sebagai menerima uang yang ada hubungannya dengan jabatannya tanpa ada catatan administrasinya. ${ }^{20}$ Menurut perspektif hukum, definisi korupsi telah dijelaskan dalam Undang-Undang Nomor 31 Tahun 1999 yang telah diubah dengan Undang-Undang Nomor 20 Tahun 2001 tentang Pemberantasan Tindak Pidana Korupsi (UU No. 31 Tahun 1999 jo UU No. 20 Tahun 2001). Korupsi dirumuskan dalam 30 (tiga puluh) bentuk tindak pidana yang dikelompokkan sebagai berikut:

1. Kerugian keuangan negara

2. Suap menyuap

3. Penggelapan dalam jabatan

4. Pemerasan

5. Perbuatan curang

6. Benturan kepentingan dalam pengadaan

7. Gratifikasi

Selain bentuk tindak pidana korupsi tersebut, ada beberapa tindak pidana lain yang berkaitan dengan tindak pidana korupsi yang tertuang dalam UU No. 31 Tahun 1999 jo UU No. 20 Tahun 2001 yaitu:

1. Merintangi proses pemeriksaan perkara korupsi

2. Tidak memberi keterangan atau memberi keterangan tidak benar

3. Bank yang tidak memberikan keterangan rekening tersangka

4. Saksi atau ahli yang tidak memberi keterangan atau memberi keterangan palsu

5. Orang yang memegang rahasia jabatan tidak memberikan keterangan atau memberikan keterangan palsu

6. Saksi yang membuka identitas pelapor ${ }^{21}$

Komisi Pemberantasan Korupsi (KPK) membuat kajian yang berisi modus-modus korupsi pengadaan barang dan jasa yang terjadi di kementerian/lembaga negara sekaligus rekomendasi pencegahan tindak pidana yang menyebabkan kerugian negara hingga mencapai Rp1 triliun. Modus yang ada adalah

1. Proyek atau paket sudah diijon atau dijual dengan 'deal-deal' tertentu kepada vendor bahkan sebelum anggaran disetujui atau disahkan.

2. Rekayasa dokumen dimana ada persekongkolan pihak terkait yang inisiatifnya bisa dimulai dari manapun juga. Kemudian ada juga Harga Perkiraan Sendiri (HPS)

\footnotetext{
${ }^{19}$ https://nasional.kompas.com, diakses pada tanggal 14 September 2020.

${ }^{20}$ Alfan Hasib, Korupsi Dari Masa Ke Masa (Surakarta: Lalunggung Media, 2012).

21 Syamsa Ardisasmita, 'Definisi Korupsi Menurut Perspektif Hukum Dan E-Announcement Untuk Tata Kelola Pemerintahan Yang Lebih Terbuka, Transparan Dan Akuntabel', Seminar Nasional Upaya Perbaikan Sistem Penyelenggaraan Pengadaan Barang/Jasa Pemerintah, 2006.
} 
dibuatkan oleh pihak yang kira-kira akan ditunjuk sebagai calon pemenang, 'mark up' harga, hingga suap dan manipulasi pemilihan pemenang.

3. Manipulasi terkait dokumen lelang, manipulasi dokumen serah terima, penerimaan suap kepada pihak-pihak terkait pengadaan barang dan jasa.

Penyimpangan dan korupsi dapat terjadi dalam seluruh proses pengadaan barang/jasa pemerintah yaitu pada:

- Tahap penentuan kebutuhan

- Tahap persiapan perancangan dan persiapan dokumen pengadaan

- Tahap pemilihan peserta dan penentuan pemenang tender

- Tahap pelaksanaan pekerjaan

- Tahap serah terima pekerjaan

- Tahap pembayaran pekerjaan

- Tahap pelaporan dan proses audit

Pertanggungjawaban PPK terhadap adanya kerugian keuangan negara, maka harus memenuhi unsur-unsur tindak pidana korupsi. Unsur-unsur tindak pidana korupsi diatur dalam pasal 2 ayat (1) UU No. 31 Tahun 1999 jo UU No. 20 Tahun 2001 yaitu

a. secara melawan hukum

b. memperkaya diri sendiri atau orang lain atau suatu korporasi

c. dapat merugikan keuangan negara atau perekonomian negara

Atau memenuhi unsur-unsur dalam pasal 3 yaitu:

a. tujuan menguntungkan diri sendiri atau orang lain atau korporasi

b. menyalahgunakan kewenangan atau sarana yang ada padanya, karena jabatan atau kedudukan dan yang dapat merugikan keuangan negara dan perekonomian negara.

Dalam kasus-kasus korupsi pengadaan barang/jasa, dijumpai pada umumnya pelaku didakwa melanggar pasal 2 ayat (1) yang dikelompokkan ke dalam bentuk tindak pidana korupsi dengan melakukan perbuatan melawan hukum untuk memperkaya diri yang merugikan keuangan negara atau perekonomian negara dan pasal 3 UU No. 31 Tahun 1999 jo UU No. 20 Tahun 2001 yang dikelompokkan ke dalam bentuk tindak pidana korupsi dengan menyalahgunakan kewenangan.

Bunyi pasal 2 UU No. 31 Tahun 1999 jo UU No. 20 Tahun 2001:

(1) Setiap orang yang secara melawan hukum melakukan perbuatan memperkaya diri sendiri atau orang lain atau suatu korporasi yang dapat merugikan keuangan negara atau perekonomian negara, dipidana dengan pidana penjawa seumur hidup atau pidana penjara paling singkat 4 (empat) tahun dan paling lama 20 (dua puluh) tahun dan denda paling sedikit Rp. 200.000.000,00 (dua ratus juta rupiah) dan paling banyak Rp. 1.000.000,00 (satu milyar rupiah) 
(2) Dalam hal tindak pidana korupsi sebagaimana dimaksud dalam ayat (1) dilakukan dalam keadaan tertentu, pidana mati dapat dijatuhkan.

\section{Sedangkan bunyi pasal 3 UU No. 31 Tahun 1999 jo UU No. 20 Tahun 2001 adalah}

"setiap orang yang dengan tujuan menguntungkan diri sendiri atau orang lain atau suatu korporasi menyalahgunakan kewenangan, kesempatan atau sarana yang ada padanya karena jabatan atau kedudukan yang dapat merugikan keuangan negara atau perekonomian negara, dipidana penjara seumur hidup atau pidana penjara paling singkat 1 (satu) tahun dan paling lama 20 (dua puluh) tahun dan atau denda paling sedikit Rp. 50.000.000,00 (lima puluh juta rupiah) dan paling banyak Rp. 1.000.000.000,00 (satu milyar rupiah)".

Tingginya kasus korupsi pengadaan penyalahgunaan wewenang yang terjadi pada pelaksanaan pengadaan barang/jasa sehingga menyebabkan kerugian negara disebabkan karena lemahnya peran pengawas dan kurangnya kesadaran hukum dari para pelaksana pengadaan barang/jasa tersebut. ${ }^{22}$

Tindak pidana korupsi merupakan delik formil yaitu adanya tindak pidana korupsi cukup dengan dipenuhinya unsur-unsur perbuatan yang sudah dirumuskan bukan dengan timbulnya akibat. Hal ini dapat diketahui dari kata "dapat" sebelum frasa "merugikan keuangan negara atau perekonomian negara" dalam pasal 2 dan pasal 3. Bahwa dapat dipidananya pelaku tindak pidana korupsi tidak perlu benar-benar terjadi kerugian negara atau dibuktikan berdampak pada kerugian perekonomian negara. ${ }^{23}$

Dalam penegakan hukum terhadap pelaku tindak pidana korupsi, sifat melawan hukum merupakan satu kesatuan dengan unsur Dapat merugikan keuangan negara atau perekonomian negara. Contoh kasus pada pengadaan barang/jasa yang terjadi di Tasikmalaya, yaitu Pengadaan KIT Bahasa Indonesia Tematik dan Alat Pendukung Sekolah Dasar di Lingkungan Dinas Pendidikan Kota Tasikmalaya Tahun Anggaran 2012. Dalam kasus ini terdakwa I (Noverdi) selaku PPK dan terdakwa II (Asep Waryanto) selaku Pejabat Pelaksana Teknis Kegiatan (PPTK) terbukti melanggar ketentuan pasal 3 jo pasal 18 huruf b UU No. 31 Tahun 1999 sebagaimana telah diubah dengan UU No. 20 Tahun 2001 tentang Pemberantasan Tindak Pidana Korupsi jo Pasal 55 ayat 1 ke 1 KUHP sebagaimana dakwaan subsidair. Dalam amar putusan disebutkan bahwa terdakwa tidak terbukti secara sah dan meyakinkan melakukan tindak pidana korupsi dalam dakwaan primer pasal 2 jo pasal 18 ayat 1 huruf b UU No. 31 Tahun 1999 sebagaimana diubah dengan UU No. 20 Tahun 2001 tentang Pemberantasan Tindak Pidana Korupsi. Apabila kita lihat kembali pasal 2 ayat (1), dapat diketahui bahwa unsur "melawan hukum" dari ketentuan tindak pidana korupsi tersebut merupakan sarana untuk melakukan perbuatan memperkaya diri sendiri atau orang lain atau korporasi. Dengan demikian akibat hukum dari perumusan ketentuan tersebut, meskipun perbuatan telah "merugikan keuangan negara atau perekonomian negara" tetapi dilakukan tidak secara

22 Beridiansyah, 'Analisis Yuridis Terhadap Pengadaan Barang dan Jasa Guna Mencegah Korupsi', Jurnal Integritas, 4 (2017).

${ }^{23}$ Elwi Danil, Korupsi, Konsep Tindak Pidana Dan Pemberantasannya, (Jakarta: Rajawali Pers, 2011) 
melawan hukum yaitu memperkaya diri sendiri atau orang lain atau korporasi, bukan merupakan tindak pidana korupsi sebagaimana dimaksud pasal 2 ayat (1). ${ }^{24}$

Dalam kasus ini sebagai PPK, terdakwa diberi kewenangan dan tanggung jawab untuk menandatangani persetujuan pembayaran kepada penyedia apabila prestasi pekerjaan sudah dilakukan 100 persen, akan tetapi dalam kasus ini terdakwa menandatangani persetujuan pembayaran kepada pihak penyedia barang yang faktanya berdasarkan hasil audit BPKP menerangkan dan menyimpulkan pembayaran yang melebihi prestasi kepada penyedia menimbulkan kerugian negara. hal ini dikarenakan terdapat volume fisik yang belum lengkap, ada komponen barang yang dikirim tidak sesuai spesifikasi teknis dan barang sebagian rusak dan sebagian tidak berfungsi.

Tindakan terdakwa menandatangani persetujuan pembayaran ini jelas tindakan melawan hukum yaitu melanggar ketentuan dalam pengadaan barang/jasa. Dengan demikian perbuatan terdakwa telah memenuhi unsur menyalahgunakan wewenang atau sarana yang ada padanya karena jabatan atau kedudukan. Pemenuhuan unsur "yang dapat merugikan keuangan negara atau perekonomian negara" dalam kasus ini didasari pertimbangan bahwa terdapat kelebihan prestasi kepada penyedia, yang apabila tidak dilakukan penyidikan maka prestasi tersebut tetap akan terbayarkan kepada pihak penyedia, yang mana akan berakibat timbulnya kerugian keuangan negara dan atau perekonomian negara.

Dalam kasus ini juga dapat dianalisa bahwa betapa pentingnya peran PPK dalam tugasnya untuk menetapkan tim pendukung dan tenaga ahli. Tim pendukung PPK yang diberi tugas menyusun kajian teknis, menyusun HPS, dan juga sebagai pengadministrasi kontrak/dokumen pengadaan, merupakan orang-orang yang dipilih PPK sesuai keahliannya untuk membantu pelaksanaan tugas PPK. Sedangkan penetapan tenaga ahli dibentuk PPK dalam kaitannya dengan keahlian yang dimiliki seorang misalnya ahli dalam hukum kontrak, ahli dalam bidang teknologi informasi. Apabila tim pendukung dan tenaga ahli tidak melakukan tugasnya dengan baik, maka dapat dipastikan proses pengadaan barang/jasa pemerintah yang dijalankan akan rawan dengan kesalahan prosedur ataupun tidak sesuai dengan peraturan perundangan-undangan yang berlaku.

Dengan dalih sibuk, PPK tidak ada waktu untuk membaca dokumen khususnya kontrak ataupun mengecek langsung dalam proses serah terima barang.

Disebutkan dalam pasal 57 dalam Perpres 16 Tahun 2018 bahwa:

(1) Setelah pekerjaan selesai $100 \%$ (seratus persen) sesuai dengan ketentuan yang termuat dalam kontrak, Penyedia mengajukan permintaan secara tertulis kepada PPK untuk serah terima barang/jasa.

(2) PPK melakukan pemeriksaan terhadap barang/jasa yang diserahkan.

(3) PPK dan Penyedia menandatangani Berita Acara Serah Terima.

${ }^{24}$ R Wiyono, Pembahasan Undang-Undang Pemberantasan Tindak Pidana Korupsi (Jakarta: Sinar Grafika, 2009). 
Dalam ketentuan tersebut jelas dinormakan bahwa yang bertanggungjawab dalam memeriksa barang pada waktu serah terima adalah PPK. Demikianpun dalam Perpres No. 12 Tahun 2021 tidak merubah ketentuan dalam pasal 57, artinya PPK tetap mempunyai tanggungjawab dalam melakukan pemeriksaan barang pada waktu terjadi serah terima hasil pekerjaan. Karena kendala PPK tidak sempat untuk memeriksa hasil pekerjaan oleh Penyedia maka peran Tim pendukung dan tenaga ahli sangatlah penting dalam rangka menjaga proses pengadaan agar tetap dalam koridor peraturan.

Pertanggungjawaban pidana seorang PPK atas perbuatan melawan hukum dalam pelaksanaan pengadaan barang/jasa pemerintah, khususnya dalam pertanggungjawaban yang bersifat pidana merupakan sanksi terberat yang dipikul oleh seorang PPK. Disisi lain ada ada bentuk pertanggungjawaban lain apabila ditinjau dari hukum administrasi dan hukum perdata. Hukum administrasi bisa berupa denda ataupun sanksi kepegawaian. Dari aspek hukum perdata bisa berupa ganti rugi atas wanprestasi yang PPK lakukan.

\section{Penutup}

PPK merupakan pihak yang sangat penting dalam menentukan sukses tidaknya pelaksanaan pengadaan barang/jasa. Tanggungjawab PPK dalam proses pengadaan barang/jasa pemerintah sangat krusial, karena hampir seluruh tahapan pengadaan barang/jasa terdapat peran PPK. Oleh karena itu pejabat PPK harus mempunyai kompetensi di bidang pengadaan barang/jasa dan mempunyai syarat manajerial. Tanggungjawab PPK dalam melaksanakan proses pengadaan barang/jasa sering berhadapan dengan masalah kewenangan dan kepatuhan terhadap ketentuan perundangundangan. Pejabat PPK yang kurang memahami peraturan di bidang pengadaan barang/jasa maka akan cenderung lalai atau teledor dalam melaksanakan proses pengadaan barang/jasa yang pada akhirnya berakhir dalam jeruji besi penjara.

Pertanggungjawaban hukum seorang PPK meliputi pertanggungjawaban jabatan dan pertanggungjawaban pribadi. Dalam hal PPK melaksanakan tindakan penyimpangan berupa kesalahan administrasi (maladministasi) dalam proses pengadaan barang/jasa pemerintah, maka pertanggungjawaban jabatan akan dijatuhkan kepadanya. Sedangkan apabila maladministrasi tersebut berimplikasi kepada pemenuhan unsur-unsur tindak pidana korupsi, maka pertanggungjawaban pribadi akan dikenakan kepada PPK, yaitu dengan bentuk pertanggungjawaban pidana yang tentunya ancaman pidananya sangat berat yaitu pidana penjara paling lama 20 (dua puluh) tahun.

Dalam upaya menjaga agar pelaksanaan pengadaan barang/jasa pemerintah tetap pada koridor peraturan perundang-undangan, maka kompetensi manajerial tetap harus dipersyaratkan untuk jabatan seorang PPK. Karena jabatan PPK merupakan tugas tambahan dan bukan merupakan tugas utama bagi seorang Pegawai Negeri Sipil, maka tidak diragukan lagi bahwa dengan kesibukannya seorang PPK tidak akan optimal dalam mengawal jalannya proses pengadaan barang/jasa, untuk itu pembentukan tim pendukung dan tim ahli sangat diperlukan dalam rangka membantu tugas PPK. 


\section{Daftar Pustaka}

\section{A. Buku}

Amiruddin, Korupsi Dalam Pengadaan Barang Dan Jasa, Genta Publising, Yogyakarta, 2010

Asikin, Zainal, et al., Pengantar Metode Penelitian Hukum, Rajawali Pers, Jakarta, 2016

Danil, Elwi, Korupsi, Konsep Tindak Pidana Dan Pemberantasannya, Rajawali Pers, Jakarta, 2011

Dwidja Priyatno, Muladi, Pertanggungjawaban Pidana Korporasi, Prenada Media Group, Jakarta, 2015

Hartanti, Evi, Tindak Pidana Korupsi, Sinar Grafika, Jakarta, 2009

Hasib, Alfan, Korupsi Dari Masa Ke Masa, Lalunggung Media, Surakarta, 2012

Marzuki, Peter Mahmud, Penelitian Hukum, Kencana, Jakarta, 2009

Moeljatno, Asas-Asas Hukum Pidana, Rineka Cipta, Jakarta, 2008

Saleh, Roeslan, Perbuatan Pidana dan Pertanggungjawaban Pidana, Aksara Baru, Jakarta, 1981

Sedarmayanti, Manajemen Sumber Daya Manusia: Reformasi Birokrasi dan Manajemen Pegawai Negeri Sipil, Refika Aditama, Bandung, 2007

Wiyono, R, Pembahasan Undang-Undang Pemberantasan Tindak Pidana Korupsi, Sinar Grafika, Jakarta, 2009

\section{B. Artikel Jurnal}

Ardisasmita, Syamsa, 'Definisi Korupsi Menurut Perspektif Hukum Dan EAnnouncement Untuk Tata Kelola Pemerintahan Yang Lebih Terbuka, Transparan Dan Akuntabel', Seminar Nasional Upaya Perbaikan Sistem Penyelenggaraan Pengadaan Barang/Jasa Pemerintah, 2006

Beridiansyah, 'Analisis Yuridis Terhadap Pengadaan Barang dan Jasa Guna Mencegah Korupsi', Jurnal Integritas, Vol. 4, 2017

Christoper M, Stuart G.G., 'WTO Government Procurement Rules and the Local Dynamics of Procurement Policies: A Malaysian Case Study', The European Journal of International Law, Vol. 17, 2006

Kristiani , Mita, 'Perlindungan Hukum Terhadap Pejabat Pembuat Komitmen (PPK) dalam Pengadaan Barang/Jasa Pemerintah pada Sistem Pengadaan secara Elektronik, Jurnal Legal Spirit, Vol 4, 2020, DOI: https://doi.org/10.31328/ls.v4i1.1552

Tiranda, Iriyanto, 'Konsep Ideal Penanganan Perkara Tindak Pidana Korupsi Pungutan Liar Berdasarkan Asas Peradilan', Jambura Law Review, Vol. 1, 2019

\section{Peraturan Perundang-Undangan}


Undang-Undang Nomor 31 Tahun 2009 sebagaimana diubah dengan Undang-Undang Nomor 20 Tahun 2001 tentang Pemberantasan Tindak Pidana Korupsi

Peraturan Presiden Nomor 16 Tahun 2018 sebagaimana diubah dengan Peraturan Presiden Nomor 12 Tahun 2001 tentang Pengadaan Barang/Jasa Pemerintah

Peraturan Lembaga LKPP Nomor 15 Tahun 2018 sebagaimana diubah dengan Peraturan Lembaga LKPP Nomor 19 Tahun 2019 tentang Pelaku Pengadaan Barang/Jasa

Surat Edaran LKPP Nomor 8 Tahun 2020 tentang Tipologi Pejabat Pembuat Komitmen dan Standar Kompetensi Pengadaan Barang/Jasa Pemerintah

\section{Internet}

Kompas, "Korupsi Pengadaan Barang dan Jasa Peringkat 2 di KPK", https://Nasional.Kompas.Com/Read/2019/11/06/11253441/Lkpp-KorupsiPengadaan-Barang-Dan-Jasa-Peringkat-2-Di-Kpk, diakses pada tanggal 9 September 2020

Khalid Mustafa, PPK tidak boleh "one man show", https://www.khalidmustafa.info/, diakses pada tanggal 9 September 2020 